\title{
GROWTH INHIBITION OF FUNGAL PLANT PATHOGENS BY ANTAGONIST BACTERIA USING DUAL CULTURE ASSAYS
}

\author{
YAN RAMONA* \\ "School of Biology, Faculty of Mathematics and Sciences, Universitas Udayana \\ * Integrated Laboratory for Biosciences and Biotechnology, Universitas Udayana
}

Received 6 April 2020 / Accepted 26 July 2020

\begin{abstract}
There has been excessive use of chemical-based pesticides globally resulting in significant environmental consequences with adverse effects on human health. Therefore, more sustainable environment friendly alternative solutions are needed to counter such environmental and health challenges. Development of biocontrol method is a sustainable solution to these challenges. The main objective of this research was to investigate the efficacy of potential antagonist bacteria to inhibit important fungal plant pathogens in vitro by applying dual culture assays on potato dextrose agar (PDA) or trypticase soya agar (TSA) media, with a view to isolate and screen potential antagonists for development of future biocontrol agents. The target pathogens were Fusarium oxysporum, Ceratocystis sp., Aspergillus flavus and Aspergillus niger, commonly found to infect horticultural plants in Bedugul village in north Bali island. The antagonist bacteria were isolated from various sources such as soil of rhizosphere zone and roots of lettuce plants and mature compost. The potential of antagonist candidates was screened on the basis of inhibitory activity against targeted fungal pathogens. Bacterial antagonists with highest zone of inhibition were identified up to genus level using biochemical tests, and the results were matched with those specified in the Bergey's Manual of determinative bacteriology. Fifteen bacterial isolates were successfully isolated from various sources, and $60 \%$ of these isolates showed antagonistic activity in vitro against fungal pathogens with various degree of inhibition. This indicated the initial potential to develop as biocontrol agents. Based on preliminary identification, genera of Bacillus and Pseudomonas were found to be the predominant isolates and in addition genus Acinetobacter was also identified in this study.
\end{abstract}

Keywords: Antagonistic, Aspergillus flavus, Aspergillus niger, Ceratogystis sp., Dual Culture Assay, Fusarium oxysporum

\section{INTRODUCTION}

Chemical-based pesticides have been used to control plant pathogens in farming practices for decades, and its application in agricultural sector into the future will continue in the short to the medium term (Bueno et al. 2017), despite the pollution challenges. These chemical-based solutions such as pesticides are used to protect agricultural crops from attack by fungi, insects, weeds, and rodents as well as lengthen the lifespan of farming products or prevent spoilage (Kumar et al. 2012). Application of chemical pesticides is also common in non-agricultural

"Corresponding author, email: yan_ramona@unud.ac.id sectors, such as sport facilities, shampoos for animals, and boats (Nicolopoulou-Stamati et al. 2016). Long term application of chemical based pesticides in agricultural and non-agricultural sectors has resulted environment and health impact in everyday life. The residue of such harmful compounds is now found in soil, waterways, agricultural crops, milk and meat causing human health challenges (Kim et al. 2016). The presence of these chemical contaminations in soil also frequently kills beneficial microbiota of soil, such as mycorrhiza and plant growth promoting rhizobacteria beyond the target pathogens. Furthermore, increase in resistance of plant pathogens may occur as a result of excessive application of such 
chemical compounds in farming practices (Lucas et al. 2015). This may also result in increased dose or innovations in new pesticides that are needed to control the same pathogens (Fernandes et al. 2010). Other studies have also reported negative impacts of pesticide exposure to the consumer and community (Andersson 2014). In terms of health impacts pesticides studies indicate neurological effects, diabetes, respiratory diseases, fetal diseases, genetic disorders and cancer in humans (Andersson 2014; Kim et al. 2017). Methyl bromide is an example of a widely used broad spectrum pesticide which was phased out in developed countries without an alternative (UNEP 2014). In addition it is claimed that these chemicals contribute to greenhouse gas emission (Heimpel et al. 2013).

Although above serious challenges exist, pesticides use in farming practices will continue and totally phasing out of such compounds will take time until better sustainable non-toxic alternatives are found (Bueno et al. 2017). Biological based sustainable technologies are being intensively researched towards the development of alternative methods to control plant pathogens worldwide. Integrated Pest Management (IPM), including the use of biological control agents to control pests and pathogens is one of the most favorable and sustainable solution paths globally.

In Bali, particularly in Bedugul Village, crop rotation in farming practices has been applied for years. Horticultural crops planted in this village include tomato, lettuce, cabbage, potato, and broccoli. At the time of sample collection, this farm was planted with lettuce plants, and therefore, the bacterial antagonists were isolated from soil in the rhizosphere zone and roots of lettuce plants from this area. In addition to these sources, we also isolated antagonists from vermi compost collected from a composting site in Denpasar city where earth worms were used as starter in the process of composting. Previous literatures for example in Gehan et al. (2018) have reported that mature composts (including vermi compost) are rich in antagonists of fungal pathogens.

Based on the above rationale, the goal of this study focused on isolation, screening, and identification of potential of bacterial biocontrol agents to inhibit plant pathogens, with a view toward the development of biocontrol agents, so that chemical-based fungicide use in the future can be reduced. The primary objective of this study was to investigate the effectiveness of bacterial antagonist isolates to inhibit the in vitro growth of several fungal plant pathogens (Fusarium oxysporum, Ceratocystis sp., Aspergillus flavus, and Aspergillus niger), commonly found to infect horticultural plants (including lettuce plants) in Bali, particularly in Bedugul area (Suryanti et al. 2013) and neighboring villages of Bedugul, including Kembang Merta village (Wulansari et al. 2015).

\section{MATERIALS AND METHODS}

\section{Fungal Pathogens}

Fungal pathogens (Fusarium oxysporum, Ceratocystis sp., Aspergillus flavus, and Aspergillus niger) were obtained from stock culture collections of the Mycology Laboratory, School of Biology, Universitas Udayana, Bali. These fungal isolates were identified in our previous study from samples collected in Bedugul Village (Suryanti et al. 2013). For regular use, these pathogens were subcultured on fresh PDA. For long-term storage, they were grown for 48 hours at ambient temperature on potato dextrose agar, cut into $1 \times 1 \mathrm{~cm}^{2}$, placed in sterile distilled water, and stored at $4{ }^{\circ} \mathrm{C}$.

\section{Sample Collection and Isolation of Potential Bacterial Antagonists}

Antagonists of plant pathogens were isolated from several sources, namely mature vermicompost (a composting site in Denpasar City), soils sampled from rhizhosphere in lettuce farm in Bedugul, Bali, and rhizoplane (roots) of lettuce plants from Bedugul, Bali. Isolation of bacterial antagonists from these sources was conducted by applying serial dilution and plating method on potato dextrose agar (PDA) or trypticase soya agar (TSA). Samples weighing 10 $\mathrm{g}$ were dissolved in saline solution $(0.85 \% \mathrm{w} / \mathrm{v}$ $\mathrm{NaCl}$ ) and volume was adjusted to $100 \mathrm{~mL}$ to obtain dilution rate of $10^{-1}$, and stomached for 20 minutes to release attached microbes on particles of soil or other samples. These samples were then further diluted in saline solution up to $10^{-6}$, and $0.1 \mathrm{~mL}$ of sample from each dilution 
was then spread onto either potato dextrose agar (PDA) or trypticase soya agar (TSA), followed by incubation at ambient temperature for $24-72$ hours. Colonies that could be distinguished appeared on media (at dilution rates of $10^{-3}$ $10^{-6}$ ) following 48 hours incubation at ambient temperature and were streaked for single colony isolation to obtain pure culture isolates. These pure cultures were then suspended in trypticase soya broth (TSB) or potato dextrose broth (PDB) with $30 \%$ glycerol in the medium, and stored at $-80^{\circ} \mathrm{C}$ (as stock cultures) until needed for further experiments.

\section{In vitro Dual Culture Assay for Screening Potential Antagonists}

Isolates of bacteria obtained previously were spot inoculated in triplicates onto the periphery of PDA or TSA plates (corresponding to the medium on which they were isolated). Plugs $\left(1 \mathrm{~cm}^{2}\right)$ of fungal pathogens were then placed in the center of the plates followed by incubation at ambient temperature or approximately at $25{ }^{\circ} \mathrm{C}$ for 1 to 7 days, after which time the inhibition zone between the antagonists and pathogens were measured from three different angles using a vernier calipers, and then averaged. Three replications were made in the experiment to obtain representative data. Isolates showing inhibition zone were subcultured on fresh PDA or TSA and stored at $4{ }^{\circ} \mathrm{C}$ for further study. For long term storage, these isolates were stored in TSB with $30 \%$ glycerol and stored at $-80^{\circ} \mathrm{C}$.

\section{Preliminary Identification of Biocontrol Agent Candidates}

Bacterial isolates showing in vitro antagonistic activity against tested plant fungal pathogens were preliminarily identified up to genus level on the basis of their morphological characteristics and specific selected tests (for soil bacterial identification) and the results were matched with those indicated in Bergey's Manual of Systematic Bacteriology (Krieg \& Holt 1984; Holt et al. 1994). The tested characteristics of bacterial antagonist candidates were: Gram stain and cell morphology, oxidative/fermentative properties, spore stain, motility, flagella stain, oxidase, urease, and catalase production, ability to hydrolyze casein, UV fluorescence, levan production, gelatin hydrolysis, casein hydrolysis, and starch hydrolysis. The procedures (preliminary identification of soil bacteria up to genus level) of all tests followed the steps specified in Ramona (2003), Suryanti et al. (2013) and Wulansari et al. (2015).

\section{RESULTS AND DISCUSSION}

A total of fifteen (15) distinguishable bacterial isolates were successfully isolated from this study. Of these, $60 \%$ of the isolates showed antagonistic activity in vitro against one or more tested fungal pathogens with various degree of inhibition (Fig. 1 and Table 1). Rhizosphere zone of lettuce plants appeared to be the best source of potential antagonists. Most bacterial antagonists isolated in this study were obtained from such zone and they showed various degree of in vitro inhibition of plant pathogens (Table 1). Surprisingly, only 2 isolates from lettuce roots inhibited the plant pathogen in vitro. Bacterial isolates obtained from vermi-compost inhibited the in vitro growth of all fungal pathogens used in the study with various degree of inhibition (Table 1). It can be seen in Table 1 that isolates A4, A5, T1, and T2 which were identified as Bacillus or Pseudomonas (Table 2 and 3) appeared to have the widest spectrum of in vitro inhibition. These isolates inhibited the growth of all tested fungal pathogens with various degree of inhibition, depending on the species of pathogens. These results provided us with initial indication of antagonists with potential to be developed as biocontrol agents. This can now be targeted for further greenhouse or field trial scale studies for validation and effective application. The inhibition zone produced by these bacterial antagonists against the targeted fungal pathogens varied between $0.86 \pm 0.11 \mathrm{~cm}$ and $3.20 \pm 0.00 \mathrm{~cm}$ (Table 1). Isolate A1 which was identified to belong to genus of Pseudomonas only inhibited the growth of Fusarium oxysporum, with inhibition zone of $1.83 \pm 0.15 \mathrm{~cm}$ (Table 1 and 2). The origin of this isolate was the rhizosphere zone of lettuce plants.

The limited number of isolates obtained in this study (Table 1,2, and 3) was partly due to the primary focus on building overall knowledge and basic tools related to in vitro cultivation of 
beneficial antagonistic microbes against fungal pathogens of Horticultural crops and from this foundation then subsequently build a wider screening system for extensive isolation of biocontrol agents. Previous reports indicated that an optimal optimized screening system is essential for in vitro cultivation from wider substrates (Weller 1988) and this study advanced this objective. Our results from this initial study were in line with Malleswari (2014) and Suthar et al. (2016) who reported similar numbers of antagonist isolates from soil samples. In synthetic media, such as TSA or PDA (considered as general media for bacteria and fungi, respectively) genera of Bacillus, Pseudomonas, and some genera belonging to enterobacteriaceae commonly grow well on such media and dominate during culturing. Bacteria or fungi with specific or unidentified need will not show growth response on such media and has been reviewed previously by Pham and Kim (2012) and as suggested only $1 \%$ of soil bacteria may be culturable on synthetic media. Therefore, there is a need for further improvement of methods as well as content and quality of synthetic media so that wider range of soil bacteria become culturable and therefore increase the probability to obtain potential isolates for biocontrol development. Pham and
Kim (2016) proposed a novel method for bacterial cultivation by applying polycarbonate permeable membrane of trans well plates in liquid cultures with common synthetic media to mimic the actual environmental conditions. By applying such method they increased numbers of culturable isolates by more than $20 \%$. Such methods will be built on the foundations of this study in future strategies.

The dual culture assays applied in our study (following isolation of antagonist candidates) appeared to be very convenient to initially indicate antagonism of bacterial antagonists against plant fungal pathogens. These results will have to be evaluated and correlated for their effectiveness in further greenhouse or field scales experiments. Overall, this is a classical method and has been used effectively to isolate and initially screen bacterial antagonists of fungal plant pathogens in vitro. Other studies recently applied this method to obtain bacterial antagonist candidates and subsequently identified the same to target fungal pathogens (Suthar et al. 2016; Wang et al. 2019); and Manandhar et al. 2019). This indicates that dual culture method is still a reliable approach to initially screen and identify antagonistic activity of a bacterial isolate against fungal or bacterial pathogens.
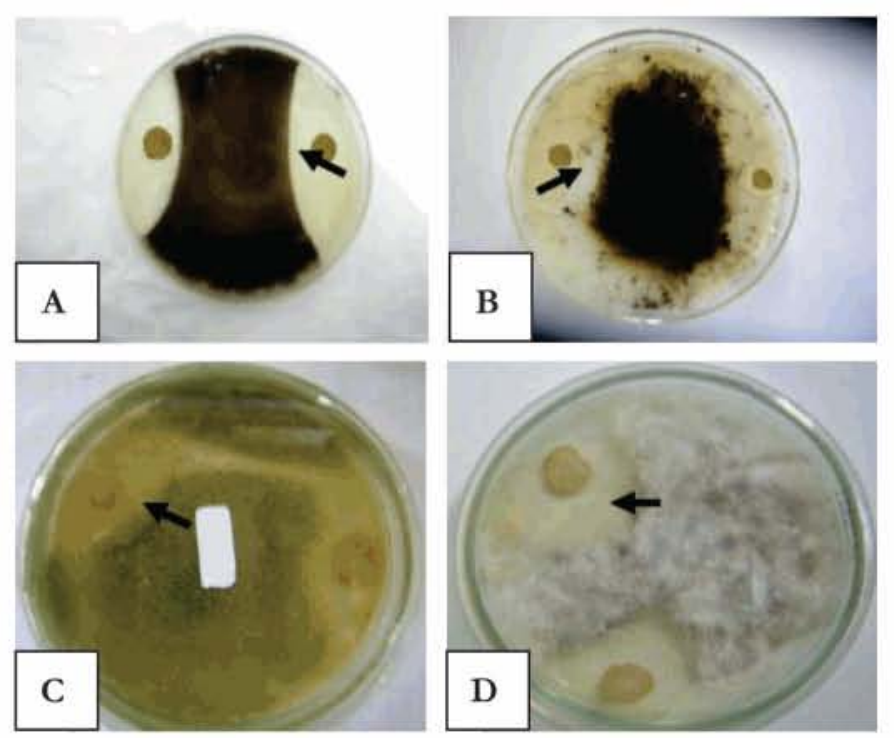

Figure 1 Some examples of in vitro antagonism between bacterial isolates obtained in this study and the tested fungal pathogens. (a) Pseudomonas sp. vs Ceratocystis sp., (b) Pseudomonas sp. vs Aspergillus niger, (c), Bacillus sp. vs Aspergillus flavus and (d). Bacillus sp. vs Fusarium oxysporum

Note: Arrowheads show the inhibition zones between the bacterial antagonists and tested fungal pathogens. 
Table 1 Average diameter of in vitro inhibition zones (on PDA or TSA media) of bacterial antagonist candidates on several plant pathogens (Fusarium oxysporum, Ceratogystis sp., Aspergillus flavus, and Aspergillus niger)

\begin{tabular}{|c|c|c|c|c|c|}
\hline \multirow{2}{*}{ Isolate codes } & \multirow{2}{*}{ Source of antagonists } & \multicolumn{4}{|c|}{ Diameter of inhibition zones on fungal pathogens $(\mathrm{cm})^{*}$} \\
\hline & & F. oxysporum & Ceratogystis sp. & A. flavus & A. niger \\
\hline $\mathrm{A} 1$ (PDA) & Lettuce rhizosphere & $1.83 \pm 0.15$ & $0.00 \pm 0.00$ & $0.00 \pm 0.00$ & $0.00 \pm 0.00$ \\
\hline A4 (PDA) & Lettuce rhizosphere & $1.06 \pm 0,06$ & $2.20 \pm 0.10$ & $1.50 \pm 0.10$ & $1.60 \pm 0.11$ \\
\hline A5 (PDA) & Lettuce rhizosphere & $3.20 \pm 0.00$ & $2.46 \pm 0.11$ & $1.33 \pm 0.11$ & $1.30 \pm 0.10$ \\
\hline A6 (PDA) & Lettuce rhizosphere & $0.00 \pm 0.00$ & $0.00 \pm 0.00$ & $0.00 \pm 0.00$ & $0.00 \pm 0.00$ \\
\hline $\mathrm{T} 1$ (PDA) & Vermi-compost & $0.96 \pm 0.06$ & $1.80 \pm 0.06$ & $1.13 \pm 0.11$ & $1.13 \pm 0.11$ \\
\hline $\mathrm{T} 2$ (PDA) & Vermi-compost & $0.86 \pm 0.11$ & $1.83 \pm 0.06$ & $1.26 \pm 0.06$ & $0.90 \pm 0.10$ \\
\hline $\mathrm{S} 1(\mathrm{TS} A)$ & Lettuce rhizosphere & $1.63 \pm 0.06$ & $0.00 \pm 0.00$ & $3.36 \pm 0.30$ & $0.00 \pm 0.00$ \\
\hline $\mathrm{S} 2$ (TSA) & Lettuce rhizosphere & $0.00 \pm 0.00$ & $0.00 \pm 0.00$ & $0.00 \pm 0.00$ & $0.00 \pm 0.00$ \\
\hline S3 (TSA) & Lettuce rhizosphere & $0.00 \pm 0.00$ & $0.00 \pm 0.00$ & $0.00 \pm 0.00$ & $1.13 \pm 0.15$ \\
\hline F1 (TSA) & Roots of lettuce & $1.50 \pm 010$ & $0.00 \pm 0.00$ & $2.70 \pm 0.10$ & $0.00 \pm 0.00$ \\
\hline F2 (TSA) & Roots of lettuce & $0.00 \pm 0.00$ & $0.00 \pm 0.00$ & $0.00 \pm 0.00$ & $0.00 \pm 0.00$ \\
\hline F3 (TSA) & Roots of lettuce & $0.00 \pm 0.00$ & $0.00 \pm 0.00$ & $0.00 \pm 0.00$ & $0.00 \pm 0.00$ \\
\hline $\mathrm{R} 1$ (TSA) & Roots of lettuce & $0.00 \pm 0.00$ & $0.00 \pm 0.00$ & $0.00 \pm 0.00$ & $0.00 \pm 0.00$ \\
\hline $\mathrm{R} 2$ (TSA) & Roots of lettuce & $0.00 \pm 0.00$ & $0.00 \pm 0.00$ & $0.00 \pm 0.00$ & $0.00 \pm 0.00$ \\
\hline R3 (TSA) & Roots of lettuce & $0.00 \pm 0.00$ & $0.00 \pm 0.00$ & $1.60 \pm 0.17$ & $0.00 \pm 0.00$ \\
\hline
\end{tabular}

Notes: * Values in Table $1 \pm$ standard deviation are averages of triplicates; PDA (Potato Dextrose Agar) and TSA (Trypticase Soy Agar) were media used in the dual culture assays.

The relative average inhibition zones shown in Table 1 varied from 0.0 to $3.36 \mathrm{~cm}$, and these apparently were affected by types and the origin of the isolates. The zone of inhibition was also determined by species of fungal pathogens tested. Generally, bacterial isolates obtained from rhizosphere of lettuce plants was found to be antagonistic against one or more fungal pathogens tested in this study (Table 1). Similar results were also reported by Ramona (2003) and Wang et al. (2019) who found abundant antagonist isolates in the rhizosphere zones of various plants. This indicates that rhizosphere area can still be considered as a reliable source of bacterial antagonists of plant pathogens for development of biocontrol agents. In addition to rhizosphere zone, antagonists can also be isolated from many sources, such as mature compost or surface of plant roots (rhizoplane) (Table 1). Some researchers have also often isolated these antagonists from suppressive soil (Schlatter et al. 2017), suppressive compost (Gehan et al. 2018), or from contaminated media in the laboratory (Ramona 2003).

The origin of the antagonist isolates is not the most important aspect in the development of biocontrol agents. The effectiveness of these antagonists in protecting horticultural plants from attack by certain pathogens either in greenhouse or field applications is apparently more important consideration than their origins. To increase the effectiveness of antagonist isolations, ideally these antagonists should be isolated from places where these agents are to be applied, as they are already well-adapted in such areas of plant systems (Whipps 2001; Ganeshan \& Kumar 2005; Dukare et al. 2018).

Spectrum of fungal pathogen inhibition in vitro of the bacterial isolates obtained from this study varied among species (Table 1). Some isolates were able to control only one tested fungal pathogen, while the other controlled two or more pathogens (Table 1). Generally, bacterial antagonists isolated from vermicompost and rhizosphere zone of lettuce plants appeared to have wider spectrum of fungal pathogen inhibition in vitro when compared to those isolated from other sources. Surprisingly, isolates obtained from Rhizoplane (hair-root surfaces) of lettuce plants were found to be less effective in inhibiting the four fungal pathogens in vitro than isolates obtained from other sources (Table 1). This phenomenon was contradictory to that reported by Wei et al. (1996) and Walia et al. (2013), but in line with that reported by Oka (2004). Although some isolates in Table 1 showed a wide spectrum of fungal pathogen inhibition, these isolates will have to be further 
tested to study their effectiveness when applied in glasshouse or field trials. Ramona (2003) reported that a positive correlation between the results of in vitro bioassay and those of glasshouse or field trials may not be necessary. The reasons for these were extensively reviewed by Whipps (2001) and O'Brien (2016) and wider testing is essential following the screening for practical application.

Although observable inhibition zones were clearly indicated in the in vitro bioassay (Table 1 and Fig. 1), the mechanisms by which bacterial antagonists may inhibit the fungal pathogens (for examples: antibiosis, siderophore production, or other mechanisms) was still inconclusive. Besides that, the effect of this antagonism (whether it was lethal or fungi static) has not yet been answered and will be considered in future studies.

Bacterial isolates with ability to inhibit the growth of at least one tested fungal pathogen were initially identified up to genus level, based on the method of soil bacterial identification specified in Ramona (2003) and Suryanti et al. (2013). The results are shown in Table 2 and Table 3. Based on these results, the genus name of the isolates was determined. One of the
Pseudomonas isolates showed fluorescence properties under UV light, in addition to the results of other tests generally used in the initial preliminary identification of soil bacteria, and therefore, it was identified as $P$. fluorescence (Table 2). Among the 9 bacterial antagonists, 5 isolates belong to Bacillus sp. as all of them produce endospore and showed characteristics of genus Bacillus as shown in Table 3.

Preliminary identification of the isolates obtained from this study showed that genera of Bacillus and Pseudomonas were predominant bacterial isolates contained in all samples (Table 2). This is in line with that reported by Kumari and Khanna (2016) and Soare et al. (2019). The presence of these two bacterial genera in the soil or other samples is relatively more abundant than others and is partly due to simpler requirements for growth of these groups when compared to others (Raaijmakers et al. 2010). The ability of Bacillus sp. to produce endospore also contributes to the survival of this genus in adverse environmental conditions (Kumari \& Khanna 2016). Besides Bacillus and Pseudomonas, genus of Acinetobacter was also isolated in this study (Table 2).

Table 2 Preliminary identification of Gram-negative bacterial antagonists

\begin{tabular}{|c|c|c|c|c|c|c|c|c|c|c|c|}
\hline $\begin{array}{l}\text { Isolate } \\
\text { codes }\end{array}$ & $\begin{array}{l}\text { Gram } \\
\text { stain }\end{array}$ & $\mathrm{O} / \mathrm{F}$ & Motility & $\begin{array}{l}\text { Flagella } \\
\text { Position }\end{array}$ & Oxidase & $\begin{array}{c}\text { UV } \\
\text { fluorescence }\end{array}$ & $\begin{array}{c}\text { Starch } \\
\text { hydrolysis }\end{array}$ & $\begin{array}{c}\text { Levan } \\
\text { production }\end{array}$ & $\begin{array}{c}\text { Gelatin } \\
\text { hydrolysis }\end{array}$ & Pigment & $\begin{array}{c}\text { Preliminary } \\
\text { Identity }\end{array}$ \\
\hline A1 & negative & $\mathrm{O}$ & + & Polar & - & - & + & - & + & - & Pseudom \\
\hline A4 & negative & $\mathrm{O}$ & + & Polar & + & + & - & - & + & - & P. fluorescence \\
\hline $\mathrm{T} 1$ & negative & $\mathrm{O}$ & + & Polar & + & - & - & + & - & - & Pseudomonas sp. \\
\hline S1 & negative & $\mathrm{O}$ & - & - & - & - & - & ND & + & Creamy & Acinetobacter sp. \\
\hline
\end{tabular}

Note: O/F: Oxidative/Fermentative.

Table 3 Preliminary identification of Gram-positive bacterial antagonists

\begin{tabular}{|c|c|c|c|c|c|c|c|c|c|c|c|c|}
\hline $\begin{array}{l}\text { Isolate } \\
\text { Codes }\end{array}$ & $\begin{array}{l}\text { Gram } \\
\text { stain }\end{array}$ & $\mathrm{O} / \mathrm{F}$ & Motility & $\begin{array}{l}\text { Flagella } \\
\text { position }\end{array}$ & Catalase & Pigment & Spore & $\begin{array}{c}\text { Starch } \\
\text { Hydrolysis }\end{array}$ & Urease & $\begin{array}{c}\text { Casein } \\
\text { hydrolysis }\end{array}$ & colony & $\begin{array}{c}\text { Preliminary } \\
\text { Identity }\end{array}$ \\
\hline A5 & positive & $\mathrm{O}$ & + & Polar & + & - & + & + & + & + & dry & Bacillus sp. \\
\hline $\mathrm{T} 2$ & positive & $\mathrm{O}$ & + & Polar & + & - & + & + & + & + & dry & Bacillus sp. \\
\hline $\mathrm{S} 3$ & positive & $\mathrm{O}$ & + & Polar & + & - & + & + & - & + & dry & Bacillus sp. \\
\hline F1 & positive & $\mathrm{O}$ & - & - & + & - & + & - & + & + & dry & Bacillus sp. \\
\hline R3 & positive & $\mathrm{O}$ & + & polar & + & - & + & + & + & + & dry & Bacillus sp. \\
\hline
\end{tabular}

Note: O/F: Oxidative/Fermentative. 


\section{CONCLUSION}

Nine out of $15(60 \%)$ bacterial isolates showed antagonistic activities against several tested fungal pathogens in the in vitro dual culture assay, although the mechanisms by which these biocontrol candidates inhibit the fungal pathogen is still inconclusive, and therefore further study is needed to specifically elucidate the mechanisms (such as antibiosis, production of siderophore, etc.) of biocontrol. In the initial and preliminary identification of these antagonists, it was found that genera of Bacillus and Pseudomonas were predominant isolates found in all samples. Besides these, genus of Acinetobacter was also isolated and identified in this study.

\section{ACKNOWLEDGEMENTS}

The author wishes to acknowledge laboratory of Mycology, School of Biology, Universitas Udayana for the provision of cultures of fungal pathogens. The Laboratory of Microbiology, School of Biology, Universitas Udayana, and the Integrated Laboratory for Biosciences and Biotechnology, Universitas Udayana should also be acknowledged for the provision of facilities and equipment during this project. Special gratitudes also go to Prof Kalidas Shetty (NDSU-USA) for his proofreading and criticism on this manuscript.

\section{REFERENCES}

Andersson H, Tago D, Treich N. 2014. Pesticides and health: A review of evidence on health effects, valuation of risks, and benefit cost analysis. Advances in Health Economics and Health Services Research. p.1-61.

Bueno ADF, Carvalho GA, dos Santos AC, Sosa-Gómez DR, da Silva DM. 2017. Pesticide selectivity to natural enemies: challenges and constraints for research and field recommendation. Ciência Rural, Santa Maria 47(06):1-10. doi: http://dx.DOI.org/ $10.1590 / 0103-8478 \mathrm{cr} 20160829$

Dukare AS, Paul SV, Nambi E, Gupta RK, Singh R, Sharma K, Vishwakarma RK. 2018. Exploitation of microbial antagonists for the control of postharvest diseases of fruits: a review. Critical Reviews in Food Science and Nutrition:1-16. doi: 10.1080/10408398.2017.1417235
Fernandes FL, Bacci L, Fernandes MS. 2010. Impact and selectivity of insecticides to predators and parasitoids. Entomo Brasilis 3(1):1-10.

Ganeshan G, Kumar AM. 2005. Pseudomonas fluorescens, a potential bacterial antagonist to control plant diseases. J Plant Interact 1(3):123-34. doi: $10.1080 / 17429140600907043$

Gehan AE, Samia HAZ, Ehab ADS, Mehreshan TEL, Abdel-Wahab AFM. 2018. In Vitro Suppressive Effect of Agriculture Residues and Municipal Solid Wastes Compost Tea on some Phytopathogenic Fungi. J Sci Res Sci 35:181-202.

Heimpel GE, Yang Y, Hill JD, Ragsdale DW. 2013. Environmental Consequences of Invasive Species: Greenhouse Gas Emissions of Insecticide Use and the Role of Biological Control in Reducing Emissions. Plos One. 8(8):e72293.

Holt JG, Krieg NR, Sneath PHA, Staley JT, Williams ST. 1994. Bergey's manual of determinative bacteriology. $9^{\text {th }}$ Ed. Philadelphia (US): Lippincott Williams and Wilkins.

Ki-Hyun K, Kabir KY, Jahan SA. 2017. Exposure to pesticides and the associated human health effects. Sci Total Enviro 575(2017):525-35. doi: http://dx.doi.org/10.1016/scitotenv.2016.09.009.

Krieg NR, Holt JG. 1984. Bergey's manual of systematic bacteriology. Vol 1. Baltimore (US): Williams and Wilkins.

Kumar N, Pathera AK, Saini P, Kumar M. 2012. Harmful effects of pesticides to human health. Annals of Agri-Bioresearch. 17(2):125-7.

Kumari P, Khanna V. 2016. Biodiversity of Pseudomonas and Bacillus possessing both bioantagonistic and plant growth promoting traits in chickpea rhizosphere. Int J Sci Nat 7(1):153-8.

Lucas JA, Hawkin NJ, Fraaije BA 2015. The evolution of fungicide resistance. Adv Appl Microbiol 90:29-2. doe: $10.1016 /$ bs.aambs.2014.09.001

Malleswari D. 2014. In vitro antagonistic activity of diverse bacterial isolates against Macrophomina phaseolina (Tassi) Goid. Int J Curr Microbiol App Sci 3(5): 755-63.

Manandhar S, Pant B, Manandhar C, Baidya S. 2019. Invitro Evaluation of Bio-control agents against Soil Borne Plant Pathogens. J Nepal Agric Res Council 5:68-72. doi: https://doi.org/10.3126/jnarc.v5i1. 23810.

Nicolopoulou-Stamati P, Maipas S, Kotampasi C, Stamatis P, Hens L. 2016. Chemical Pesticides and Human Health: The Urgent Need for a New Concept in Agriculture. Front Public Health 4:148. doi: $10.3389 /$ fpubh.2016.00148.

O'Brien PA. 2016. Biological control of plant diseases. Australasian Plant Pathol 46(4). doi: 10.1007/ s13313-017-0481-4. 
Oka IB. 2004. Imunisasi tanaman cabai merah (Capsicum annum L.) terhadap Colletotrichum gleosporiodes (Penz.) Sacc. dengan penginokulasian rizopseudomonas nonpatogenik. Jurnal Biologi Universitas Udayana $8(2): 41-5$.

Pham VHT, Kim J. 2012. Cultivation of unculturable soil bacteria. Trends in Biotechnology 30(9):475-84. doi: http://dx.doi.org/10.1016/j.tibtech.2012.05. 007.

Pham VHT, Kim J. 2016. Improvement for Isolation of Soil Bacteria by Using Common Culture Media. J Pure Appl Microbiol 10(1):1-11.

Ramona Y. 2003. Assessment of some antagonists to fungal plant pathogens and development of methods for their large scale cultivation. [Dissertation]. Tasmania (AU): School of Agricultural Science, the University of Tasmania Australia.

Raaijmakers JM, De Bruijn I, Nybroe O, Ongena M. 2010. Natural functions of lipopeptides from Bacillus and Pseudomonas: More than surfactants and antibiotics. FEMS Microbiol. Rev 34:1037-62.

Ristaino JB, Thomas W. 1997. Agriculture, methyl bromide, and ozone hole. Plant Disease. 81:964 77.

Schlatter D, Kinkel L, Tomashow L, Weller D, Paulitz T. 2017. Disease suppressive soil: New insight from the soil microbiom. Phytopathology. 107(11):128497. doi: http://doi.org/ 10.1094/PHYTO-03-170111-RVW

Soare GM, Lakatos ES, Ene N, Malo N, Popa O, Babeanu N. 2019. The Potential Applications of Bacillus sp. and Pseudomonas sp. Strains with Antimicrobial Activity against Phytopathogens, in Waste Oils and the Bioremediation of Hydrocarbons. Catalysts 9:959. doi:10.3390/ catal9110959

Suryanti IAP, Ramona Y, Proborini MW. 2013. Isolasi dan identifikasi jamur penyebab penyakit layu dan antagonisnya pada tanaman kentang yang dibudidayakan di Bedugul, Bali. Jurnal Biologi. XVII (2):37-41.

Suthar KP, Patel RM, Singh D, Parekh VB, Khunt MD, Ahmad T. 2017. Isolation and characterization of antagonist bacteria from chickpea rhizosphere against Fusarium oxysporum f. sp. ciceris. J Pure Appli Microbiol 11(1):371-8.

UNEP. 2014. Phasing out Methyl Bromide in Developing Countries: A success story and its challenges. United Nations Environment Programme.

Walia A, Mehta P, Chauhan A, Sirkot CK. 2013. Antagonistic Activity of Plant Growth Promoting Rhizobacteria Isolated from Tomato Rhizosphere Against Soil Borne Fungal Plant Pathogens. Int J Agric Environ Biotech 6(4):587-95.

Wang X, Li Q, Sui J, Zhang J, Liu Z, Du J, Xu R, Zhou Y, Liu X. 2019. Isolation and Characterization of Antagonistic Bacteria Paenibacillus jamilae HS-26 and Their Effects on Plant Growth. Hindawi BioMed Research International. 2019(ID 3638926). 13 pp. doi: https://doi.org/ 10.1155/ $2019 / 3638926$

Weller DM. 1988. Biological control of soilborne pathogens in the rhizosphere with bacteria. Annu Rev Phytopathol 26:379-407.

Wei G, Kloepper JW, Tuzun S. 1996. Induced systemic resistance to cucumber diseases and increased plant growth by plant growth-promoting rhizobacteria under field conditions. Phytopathology 88:35.

Whipps JM. 2001. Microbial interaction and biocontrol in the rhizosphere. J Experiment Bot 52 (Root special issue):487-511.

Wulansari N T, Ramona Y, Proborini MW. 2015. Identification of Xanthomonas campestris isolated from rhizosphere zone of broccoli farm at Kembang Merta village, Tabanan-Bali. Jurnal Metamorfosa Vol II(1):29-33. 